\title{
China Pakistan Economic Corridor (CPEC): International Media Reporting and Legal Validity of Gilgit-Baltistan
}

\author{
Muhammad Asif ${ }^{1} \&$ Yang Bo Ling ${ }^{1}$ \\ ${ }^{1}$ School of Journalism and Communication, Anhui Normal University, Wuhu, China \\ Correspondence: Muhammad Asif. E-mail: asifanu@hotmail.com
}

Received: December 18, 2018

Accepted: Janaury 3, 2019

Online Published: January 30, 2019

doi:10.5539/ass.v15n2p177

URL: https://doi.org/10.5539/ass.v15n2p177

\begin{abstract}
New Silk Road Initiative is known as Belt and Road Initiative (BRI), an initiative which connect the China to the world for establish a free trade zone. China Pakistan Economic Corridor (CPEC) is one of the mega project of BRI that strengthen the relationship between Pakistan and China. It was started with the initial value of $\$ 46$ billion for the development of transportation, infrastructure, and energy projects in Pakistan which has reached to $\$ 62$ billion now. CPEC projects are going to open a new door of progress in Pakistan and also getting an attention of international media to highlight the opportunities and challenges of these ongoing projects. The aim of this study is to observe the international media reporting about the CPEC by examining the international news which was reported in the following international newspapers regarding CPEC, such as Dawn News (Pakistan), Global Times (China), Times of India (India) and BBC News (UK). News reported from January 2018 to June 2018 has the part of my study and tried to find out that the way of international media to shatter the news and what are the differences and similarities among the news reporting. The study has also discussed and clarified the legal territorial right of the regions of the CPEC, especially the Gilgit-Baltistan.
\end{abstract}

Keywords: media reporting, international media, New Silk Road, Pak-China Relations, Gilgit-Baltistan, territory

\section{Introduction}

Due to the continuous progress from the last few decades, China is a major focus of international media headlines and international affairs of the world in terms of political, economic and diplomatic domains of global power have scholarly garnered. So far researched about China's inflate ties diffusion from corner to corner of South Asia (Chen, Banerjee, Toor, \& Downie, 2014). This initiative is 2000 years old project such as "Silk Road" that is known as "One Belt One Road" which is integrating the many countries through CPEC. CPEC enhanced the value of Pakistan not only at regional level but also in global politics. It is one intersection Shackle in which China is hopeful for sustainable development and global integration. China and Pakistan have a long history of strategic relations since 1990, Pak-China relations will be closer, due to the initiation of strategic cooperation in all fields like economic, investment and trade. Chinese president Xi Jinping visit Pakistan in April 2015 and announced many mega projects. Moreover, these projects came into an outline with a massive initial investment of $\$ 46$ billion in different projects, included railways track, energy, roads, oil and gas pipelines, fiber optic cables, industrial development and construction of Gwadar port. Due to the importance of this CPEC projects, it is necessary to evaluate the international media opinions about this corridor. Pakistan is facing many problems internally and externally to make successful of this project. India raised question about Gilgit-Baltistan and Kashmir region and presenting as a dispute territory because CPEC project will passes through Jammu and Kashmir region. Gilgit-Baltistan is a province of Pakistan and included the territory of Pakistan, and Pakistan has a complete control of its territory and has rights to develop the region. Pak-China clearly stated that the CPEC will not create any threat to other countries.

\section{Historical Importance of CPEC}

Pak-China relations started since 1950 (Arif, 1984) and relations were improved after the trade agreement in 1953 (Dixit, 1987). In 1954-55, signing on SEATO and CENTO among Chinese made some suspicion, and feel to be a threat to regional and national security. Pakistan makes it clear that these signed is only for safeguard against the Indian threat (Syed, 1974). Pakistan used the Bandung Conference to clarify the uncertainties and China authenticates in this conference that Pakistan is seven pillars of peace (Chaudhri, 1970). From the 1970s 
the relation between the two countries in all sectors became stronger. China raised Pakistan in military and economic sector, even during the time of restriction imposed by some countries. People of Both countries build their confidence through the friendly policies. The outcome of this long-standing friendship, we can see a great achievement in terms of China-Pakistan Economic Corridor (CPEC). The notion of Silk Road was retold by China in 2013 under BRI Economic Belt along the Silk Road for regional integration to see the economically demands of the global world (Mahar, 2015). China and Pakistan is a significant partner. Silk Road links China to Central Asia, Middle East, Southern Asian regions, and its Gwadar port offers direct access to the Indian Ocean and beyond. Both countries are working on strategic communication to save their common interest. CPEC is a model of cooperation; it will bring a change at the international and regional level and also serve against the backdrops. Over the years both countries have established strong economic ties and bilateral trade, China has become a major partner in imports and exports. Sino Pakistan cooperation of bilateral trade and economic was impacted in 2012, through numerous factors both in Pakistan and rest of the world. In May 2013 premier Li Keqiang during his visit to Pakistan, he quoted welcome Pakistan with a catchphrase that "good neighbors are a blessing" and emphasized that Pakistan is an "iron" friend, trustworthy for China. Moreover, Chinese people called “Ba Tie" 巴铁 (Iron Brother and trustworthy Pakistan)" (Xinhuanet, 2013).

In April 2015 Chinese President Mr. Xi came to Pakistan, and both sides decided to boost up the relationship in the direction of all-weather strategic partnership (Lu, 2015). During his visit, China and Pakistan signed fifty-one agreements (Khan, n. d.). CPEC is a 'flagship project' of BRI and the economic \& energy corridors openly designed to encourage economic growth. CPEC project is a collection of various projects that would be accomplished in various stages through bilateral agreements which is approved by both countries as a win-win equation (Khan, 2017). The initiative was encouraged in different parts of Asia to accelerate economic growth by connecting backward regions by establishing the industrial centers, incorporation of trans-border and advance access to markets production networks (Ranjan, 2015). The main part of CPEC is Gwadar port, industrial zones, energy infrastructure, and communication infrastructure (Rizvi, 2015). The main theme of this corridor is to improve and uplift the life of people throughout the country and long-term socio-economic prosperity and political stability (Tiezzi, 2016). Moreover, it will connect the countries such as Egypt in the Middle East, European Countries and important global points in Eurasia. The network growing in the form of Land Silk routes and $21^{\text {st }}$ century Maritime Silk routes will connect the regional countries through trade and economic boom in the region (Ijaz, 2016). In 2010, China stated Kashgar is an imperative transit point that is located on the ancient Silk Route and a doorway between both countries and a Special Economic Zone (SEZ) for the development of Xinjiang Province of Western China that will lead the main trading within Central and South Asia, integration of energy and economic (Rafi, 2016). Russia also interested in the ongoing projects and will provide access to the warm waters (One Belt One Road Provides New Drive for Regional Sustainable Development, 2016).

The Ambassador of Pakistan in China Masood Khalid stated that "The territory of Pakistan is like a corridor which links China with the Arabian Sea, and it can play a role of a bridge between China and the world" (Paracha, 2016). CPEC will be renovated to be a bridge that would also link Pakistan to Central Asia through a 1300-Kilometer-long Optic Fiber Project (Paracha, 2016). President Xi of China during his address to the Foreign Affairs Committee at Communist Party meeting in 2014 said that we will give priority to our neighbors in our diplomacy. While, other parts of policy to build relations with developing countries having the abundance of natural resources, including energy-rich countries. It will help China to be branded as the development partner and non- interfering ally in the prosperity of nations (Godement, 2014). The goals to build this corridor surfaced over a decade and a half ago and because of the instability of the region and international involvements, the CPEC is not being funded either through the Silk Road Fund or the AIIB (Wang, 2015). China builds a leading role in Asia and beyond through BRI with political and economic cooperation. Many experts imagine that it is not only economic or trade initiative but also a plan for spreading out of China's role in the world (Wang, 2015). Development bank, Asian infrastructure and naval bases in different countries being referred to as an example. Asian Infrastructure and Development Bank considered as competitive being financial system and USA supremacy in the financial sector on the international level (Xu, 2015).

In the implementation of CPEC Pakistan is facing many problems externally and internally. The Vice Director General of Policy Research Office at the International Department of the Central Committee Communist Party of China, Dr. Luan Jianzhang observe that political unrest, security situation, and managerial issues are the greatest challenges in the completion of this corridor. The construction of CPEC has been strategically defined that Pakistan has an envisage position of economic pivot for the whole region. This strategic position of Pakistan from inside and outside is a great worry for opponents, India, Israel and the US is unhappy. For India, CPEC is a thorn in its paw and in Delhi RAW has opened a special office and spends $\$ 300$ million to disturb the CPEC 
project. India is trying to create a terror in three restless regions of Pakistan, and start NGOs, think tanks to spread uncertainties and horror (International New York Times, 2015). With Western pressures and facilitation India creating roadblocks between China and its dream of developing the BRI in spite of being a part of the BRI. India has obstructed China's effort to get membership in the South Asian Association for Regional Cooperation (SAARC) that China aimed to promote its efforts for the BRI. Now India is creating stronger ties with Vietnam and Japan that is challenging for China over regional, disputes. Now Prime Minister Modi has voiced his concerns over the CPEC being "unacceptable" (timesofindia).

\section{Methodology}

This study will spotlight on the reporting of international media on CPEC projects, its influence on Pakistan foreign policy as well as relationship between Pak-China. Pakistan is facing several issues regarding CPEC projects. These issues were also covered by different news reports. This study analyzes that how international media reported the whole story related to these projects. Media reporting from January 2018 to June 2018 explored in order to analyze the qualitatively impact of these international media reports and territorial rights of the region related to CPEC. This study considered following four international newspapers such as Dawn News, Global Times, The Times of India, and BBC news.

\section{The Aim of Study}

Media can play a vital role by serving as bridge in promoting the spirit and essence of the CPEC. The aim of this study is to analyze and evaluate the media news regarding CPEC, which is going to promote the cooperation among the regions of BRI. That How international media spreading the news regarding CPEC projects and its legal validity, and there what is the reality in news. What are the reasons behind the international media propaganda against the legal validity and territorial rights of the regions of CPEC?

\section{Media Reporting}

This part explained the variant news reports that are published in the international newspapers about the CPEC. These research reports have discussed the impact and other issues regarding CPEC projects.

"Times of India" reported that "To protect CPEC, China has been secretly holding talks with Baluch militants in Pakistan: Report" China secretly talk with Baluch militants to secure $\$ 60$ billion projects of CPEC, in Financial Times newspaper told that just three people knew about conversation between them. Pakistan official said by FT "China has silently made countless progress." Yao Jing said there is no longer threat from Baluch militants about CPEC. They also reported the claim of Baluch militants, the aim of CPEC is to change the demography of Baluchistan and to stop the illegal construction in the Baluch regions by Pak-China projects. Ten Pakistani were killed near Gwadar port during working last year. The Pakistani official said, "Even separatists sometimes tried to do attacks but they were not making an influential push". FT reported that one of the official welcome to talk between Baluch rebels and China. One of the official from Islamabad said that, "Ultimately if there's peace in Baluchistan then it will be in favor of both of us." Pakistan is not worried about Chinese interference in its internal matters because both countries have very good relationships over the years. Moreover, Baluch will continue to support the Islamabad policies even though the crisis with Washington. Beijing has directly talk with militants in Pakistan and it may pay a small price for support because this region has also stakeholder of CPEC projects (times of India).

"Dawn news" reported the news with the following headline such as "Baluch militants no longer a threat to CPEC, says Chinese envoy" Chinese Ambassador to Pakistan Yao Jing said the Baluch militant is no longer threat for CPEC. In this interview of BBC Urdu, he said with a confident that security situation has improved in last few years. Soon Gwadar port will become a world's trading hub around the globe. Moreover, he said, "If they [Baluch militants] are true Pakistanis, then they should work in the best interest of Pakistan." Mr. Yao stated that he is satisfied with the security efforts of Pakistan. 10,000 Chinese nationals are working in different projects of CPEC in Pakistan and 60,000 local people are working on different jobs (dawn news). "CPEC vital for Pakistan's economy: Baluchistan speaker" Ex. Baluchistan Assembly Speaker Raheela Hameed Durrani said CPEC will play a vital role in the economy of Pakistan and it is the need of time to understand the various aspects and sensitivity of this multibillion-dollar projects. CPEC project will be a game changer not only in Pakistan but also for the whole region (dawn news).

Global Time reported that the "Investment from multiple sources good for Pakistan" China did talk with Baluch tribal and peruses them for exchange economic regional benefit and lay down the weapons. China is promoting the cooperation and investment environment that will be benefit not only for Pakistan but also other foreign investors and will encourage them to invest in Pakistan (global time). 
Dawn reported that "China in talks with Baluch militants to secure CPEC projects, says FT" "China holding talks with Baluch militants in an effort of more than five years to protect $\$ 60$ billion. Financial Times claimed that " China quietly talks with Baluch militants more than half a century to protect $\$ 60$ billion of the project that is a part of CPEC. One of the Pakistan official told that financial times "China making a lot of progress, while separatists from time to time tried to do attacks, they did not make an assertive push". From more than five decades China is following its policy of non-interference but the settlement with the Baluch militants by China showed his desire to protect the billion dollars' investment to complete the New Silk Road, which will spread almost around the globe. Pakistani official welcomed the Chinese envoy to talk with Baluch rebels, the paper claimed even if they don't know what has been discussed. One official said in Islamabad "Eventually if there is peace in Baluchistan, that will benefit both of us." The official said "[The Chinese] are here to stay and help Pakistan, unlike the Americans, who cannot be trusted," The Chinese official said in an interview on BBC that there is no longer threat from Baluch-militant to CPEC. One provincial tribal leader informed that with the promise of financial benefits many young men lay down their weapons. He said, "Now young men are not interested to connect the insurgents such as 10 years ago they did." He added "Now a lot of people want to see prosperity" as a result of the CPEC (dawn news).

Comparatively news published in above newspapers, in which Indian media making an immature reporting that China is making interference in the personal affairs of Pakistan and Pakistan is not worried about Chinese interference in its internal matters. From more than five decades China is following its policy of non-interference but the settlement with the Baluch militants by China showed his desire to protect the billion dollars' of investment to complete the New Silk Road, which spread almost around the globe. Even Pakistani official welcomes to Chinese envoy to talk with Baluch rebels, the FT paper claimed even if they don't know what has been discussed. CPEC project is a game changer for Pakistan that will promote peace, prosperity and also will generate 60,000 local jobs and exchange economic regional benefit for Pakistan and also for whole region.

Times of India reported the following news about the Gilgit-Baltistan (GB) that the "China mum on Pakistan's Gilgit-Baltistan order, says CPEC will not affect its stand on Kashmir". New Delhi reacts with strong anger and said that, the whole state Jammu and Kashmir include GB area all is a part of India since 1947. Spokesperson of Chinese Foreign Ministry Hua Chunying during media briefing told that "Kashmir issue is a historical baggage between India and Pakistan and therefore shall be resolved between the two sides through dialogue" further she said "we have stressed many times that the CPEC is an initiative for economic cooperation. This is a cooperation framework which serves the purpose of economic development and the people's livelihood. This initiative does not affect our position on the Kashmir issue" (times of India). "India lodges protest with Pakistan deputy HC over GB order" "Pakistan plan to integrate GB area to make easy for CPEC project to pass through India, and India will remain opposed of CPEC project due to sovereignty aspect. GB region declared as the fifth province is "entirely unacceptable" because of disputed on Kashmir issue and India told that state of Jammu and Kashmir entire area is the part of India. The MEA said, "Pakistan has no legal basis and any action of any part of the territory under violent and illegal occupation, and it is entirely unacceptable, Pakistan should vacate all areas under its illegal occupation, rather than pursuing to alter the status of the occupied territories." (times of india). "Pakistan will give more financial powers to Pakistan Occupied Kashmir (PoK)" GB is treated as a separate province like Sindh, Punjab, KPK, and India term as "entirely unacceptable" because of dispute on Kashmir. India protest over CPEC that is pass-through GB region, it believed that China prompt to change the unsettled status to settled of GB (time so findia). "India sticks to its own path, says no to China's Belt and Road initiative" India in the meeting of SCO stood out only one country against the Chinese ambitious BRI due to Pak-China economic corridor CPEC that will violate of its sovereignty, as it will pass through Pakistan-occupied Kashmir (times of India).

Times of India also reported that "Pakistan suspects India may target CPEC installations" Pakistan interior ministry quoted by a media report, that India planned to destruct the installation of CPEC project and Pakistan ministry already informed to GB home department about this fact which is reported by Dawn news. The ministry ordered to make full proof security and federal interior ministry received a letter in which warned possible attacks on CPEC route. Moreover, provincial government also enhance the security on the CPEC routes. Home secretary of GB Jawad Akram visited there and reviewed the security arrangements. IGP Sabir Ahmed held the meeting and said CPEC route of Karakoram Highway (KKH) had been declared sensitive and foreigner's movements will be monitored, and also documents would be verified. He said, "Suspected persons in the region will be detained" (times of India). Times of India "India refuses to endorse China's BRI" Indian Prime Minister in his address during SCO Shanghai cooperation organization at QINGDAO he said BRI mega connectivity project should respect territorial integrity and sovereignty the project of CPEC as the part of BRI and will pass 
through (PoK) Pakistan-occupied Kashmir it is unaccepted because it ignores the territorial integrity and sovereignty (times of India).

Dawn reported that the "India asked to review short-sighted approach to CPEC" Ahsan Iqbal Minister for Planning, Reforms, and Development said India should gain benefit from CPEC project, instead of criticizing. He said in a press conference that New Delhi reviewed this project with a short-sighted approach. He said that "CPEC project is an economic and development project that will bring peace and prosperity in the region. India should gain an advantage from this project instead of hunting pointless criticism". India will realize sooner or later that the project would benefit for the whole region. He stressed for strong cooperation and India can play a vital role in South Asia for peace and progress further he said "Transport corridors will play a vital role in economic integration and will be helpful to link the countries for trade and regional connectivity across the globe," he said regional cooperation will open new door of progress by enhancing connectivity through Central Asia of economic cooperation with other markets of the world. He said "CPEC will open new means for market access through Central Asia to other parts of the world. (dawn news)."

Dawn News reported that "India may target CPEC installations, interior ministry tells GB" India has made a plan to disturb the installation of multi-billion projects CPEC and the interior ministry has informed the Gilgit-Baltistan's home department. An official of home department told Dawn they have received a letter from federal interior ministry in which informed them for possible attacks on the CPEC route. He claimed that India sent 400 Muslim youngsters to Afganistan for training to disturb CPEC installation and bridges of Karakoram Highway (KKH). Gilgit-Baltistan home department asked to make sure foolproof security. GB home secretary and IGP Sabir Ahmed visit there and held a meeting and in this IGP Sabir declared sensitive KKH bridges and CPEC route. He advised keeping an eye on suspected persons. IGP told in a meeting that security should be ensured of CPEC project, it is important for the region. IGP said foreigners' movements and their documents should be verified and he said, "Suspected persons in the region will be detained under the Fourth Schedule." Last year GB police caught 12 workers with a large number of weapons and police also informed media that they received funds from RAW to create disturbance in the CPEC project and in Gilgit-Baltistan (dawn news).

"Global Times" reported "CPEC can build bridges between India, Pakistan through economic cooperation," Pakistan Prime Minister Shahid khaqan Abbasi said Pakistan and India dispute over Kashmir, India New Delhi should watch it carefully as it passes through Azad Jammu and Kashmir, that India declared a sovereign territory. India should take CPEC in view of economic cooperation B\&R initiative increasing global attention and its success for New Delhi make more difficult to keep away from its influence. India should think seriously about this project and should relinquish of its prejudice. With the development of Gwadar port, new trade routes would be beneficial for all other Asian countries including India. CPEC integrate the region and will improve infrastructure, economic growth. Despite conflict between Pakistan and India, some Pakistani suggested joining CPEC can invite India. There is the intention of China to use CPEC against India, in fact, CPEC will promote reuniting between Pakistan-India with economic cooperation (global times). "Informal Xi-Modi meeting herald's new chapter in Sino-Indian relations" Chinese president Xi and Indian Prime Minister Modi held an informal meeting in Wuhan, Hubei Province. In this meeting, China encourages to resolve the Kashmir issue of both countries India-Pakistan with a peaceful way and convinced that CPEC project is an economic cooperation project would not affect China's neutrality (global times).

Indian media reports about GB and Kashmir region is presenting as a dispute territory because CPEC project will passes through Jammu and Kashmir region. New Delhi showed his anger and said GB is "entirely unacceptable" because Pakistan treating like separate province. In fact, GB and Azad Kashmir both are under the sovereignty of Pakistan. India media raised such kind of questions in order to destruct the installation of CPEC and is trying to create hurdles. In legal perspective, territory normally indicates a geographical area that has been obtained by a particular country but has not been recognized as a full participant in that country's affairs. Gilgit-Baltistan is a province of Pakistan and included the territory of Pakistan. Pakistan has a complete control of its territory and has rights to develop the region. CPEC project is an economic and development project that will bring peace and prosperity in the region. India should gain advantage from this project instead of hunting pointless criticism. Chinese president Xi and Indian Prime Minister Modi held an informal meeting in Wuhan China encourage to resolve the Kashmir issue of both countries India-Pakistan with a peaceful way and convinced that CPEC project is an economic cooperation project would not be affect China's neutrality.

Times of India "Chinese prisoners working on CPEC in Pakistan: MP" A member of National Assembly Nawab Mohammad Yousuf Talpur in a meeting of parliamentary committee said, "Chinese prisoners came from Chinese jails for constructing roads and there should be proper security arrangements because they can be involved in crimes so." Talpur quoted Dawn, the question to authorities had they any tacit agreement with Beijing and he 
said "he contact with an official concerned who told him that prisoners had been working in Pakistan. The interior Minister instead of rejecting his claim in return just said it was not in the knowledge of the ministry. his doubt was strengthened by an ambiguous response". MNA said he supposed that secret agreement had become between both countries "without taking into the confidence of host nation prisoners cannot send from one country to another. Prisoners as laborers are using in Chinese construction companies." Lawmaker should take notice against Chinese nationals who had been caught in ATM fraud cases in the port city of Karachi, about the presence of Chinese prisoners home ministry showing unaware in the report. Interior Secretary Rizwan Malik told that security of Chinese workers contains in three layers "In CPEC projects there are different security arrangements for Chinese national's workers. Who have come for electricity projects for them have been Separate security arrangements." He further added that security arrangements also made for Chinese students and businessmen. (times of India).

Dawn also reported the news about the issue of Chinese prisoners, "Chinese prisoners working on CPEC projects: MNA" Nawab Mohammad Yousuf Talpur a Member of National Assembly (MNA) talk about security to provides Chinese and Pakistanis. He said many Chinese prisoners are working in different projects of CPEC. He said, "that many prisoners have been brought for roads constructing from Chinese jails, so there should be proper arrangements of security they can be involved in crimes," and the Ministry of Interior in Pakistan showed lack of knowledge about the Chinese prisoners. Rizwan Malik Special Secretary of Interior told that Chinese workers security being formed in three layers, "In CPEC projects there is a separate security arrangement for Chinese national's workers for those who have come for electricity projects." and also for Chinese students and businessmen. MNA Talpur told the Dawn that he got information that many Chinese prisoners are working in CPEC project in the whole country and said, "He make contact with official concerned and confirmed that Chinese prisoners working in Pakistan. The Ministry of Interior does not rebuff his claim and then his doubt made strong by an indistinct reaction from the ministry that it was not in their knowledge". He was surprised to bring prisoners from China. He said "Between both countries agreements are unannounced and without taking the host nation into confidence prisoners from one country to another cannot be sent. prisoners are using as laborers in Chinese constriction companies." MNA Talpur told that in Karachi many Chinese caught by in ATM fraud cases. He said, "I suppose that in computerized crimes prisoners are involved and ATM theft crimes and Pakistanis are not able to carry out such kind of crimes." The committee proposes to provide Rs500 million of the Federal Investigation Agency (FIA) to the cyber crime wing. Director FIA Mohammad Shoaib during meeting told that 13,000 complaints received by cybercrime wing. "it is very difficult to examine all the complaints because We have only 15 investigating officers." He said to resolve the pending cases FIA have the need to assign 444 officials in cybercrime (dawn news).

Global Times reported "China to enhance cooperation on law enforcement security with other SCO countries" Zhao Kezhi Chinese state councilor met with the member of six other countries in Shanghai Cooperation Organization (SCO) in perspective to improve cooperation on law enforcement security. The $13^{\text {th }}$ meeting Security Council Secretaries SCO in Beijing they talk about issues and regional security situation main concern to enhance security cooperation amongst SCO members. In meeting with Pakistan's national security adviser Naseer Khan Janjua, Zhao said China is ready to enhance bilateral cooperation on anti-terrorism, transnational crime and also security issues along CPEC. In meeting deputy, national security adviser of India Rajinder Khanna, Zhao said China would work with India to promote a healthy environment for the stable development of bilateral ties and improve the cooperation mechanism also will enhance cooperation on anti-terrorism. Khanna said India is ready to work with China to enhance cooperation on security law enforcement (global times).

Indian newspaper report did not describe the whole story about the issue which rose by Talpur in parliamentary meeting. He supposed that in ATM theft crimes Chinese prisoners are involved and Pakistan is not able to carry out such crimes. He talked about to improve security arrangements with Interior secretary Rizwan Malik and Interior secretary said that there is three layers of security provide to Chinese workers who are working in CPEC projects and further explained that parliamentary committee will also issue five hundred million to FIA for appointing 444 officers to control the cyber-crimes in the country. In meeting with Pakistan's national security adviser Naseer Khan Janjua, Zhao said China is ready to enhance bilateral cooperation on anti-terrorism, transnational crime and also security issues along CPEC.

Pakistan local Urdu news channel reported on 19 February as "breaking news" that "Senate approves the motion to declare Chinese as official language" (abbtak.tv). Pakistani parliament passed a resolution Chinese-language "recommending" courses taught in Pakistan and there is no suggestion that the Chinese language becomes an official language. Chinese courses launched to reduce "communication barriers" of CPEC project. This news spread fast in Pakistan and also across the border. Several Indian media misreporting pick-up including India 
today, ANI news agency reported: "Mandarin approved as the official language of Pakistan" (http://www.aninews.in/news/world/asia/mandarin-approved-as-official-language-of-pakistan201802192310240 $006 /)$.

Financial Express reported "Pakistanis employed with CPEC project to learn Mandarin Senate approves motion" "under the CPEC with growing collaboration between China and Pakistan, Chinese Language courses of the Official should be launched for all Pakistani CPEC human resource to overcome any costly communication barriers" and admitted that News agency ANI misreporting about it (indiatoday). India today also reported "Ni Hao: Pakistan Senate approves a motion to teach Chinese in government schools" and admitted false reporting about this report (financial express). BBC news reported "Reality Check: Is Chinese an official language in Pakistan?" About it that Pakistan Senate did pass the resolution but all called it "official Chinese language" courses to be taught to reduce "communication barriers" for CPEC project. India several media spread this news wrongly including India Today, Financial Express and ANI news agency. After that, they admitted their incorrect report and in China also reacted on this fake news from the Shanghai Academy of Social Sciences, Hu Zhiyong calling it is an attempt to create a problem between China and Pakistan (http://www.bbc.co.uk/news/world-asia-43158523). Hu Zhiyong a research fellow institute told the Global Time "India media uses fake news to drive a wedge between China and Pakistan: expert" The Senate of Pakistan on Tuesday tweeted that "in light of the growing affiliation and collaboration between China and Pakistan under the CPEC, courses of the official Chinese language, also known as the 'Standard Chinese,' may be made accessible so as to overcome any costly communication barrier." He further explains "Some Indian media picked up the false news in order to drive a wedge between China and Pakistan" (global time).

Pakistan local news channel first break the news that Pakistani parliament passed a resolution Chinese-language "recommending" courses taught in Pakistan and there is no suggestion that Chinese language become an official language. Chinese courses launched to reduce "communication barriers" of CPEC project. Indian media including India Today, Financial Express and ANI news agency spread this news wrongly, it is an attempt to create a problem between China and Pakistan.

\section{Similarities and Differences}

China is going to connect the two thirds population of the world and there are 60 countries includes in BRI. Pak-China has strong relations throughout the history and has a goal to make successful of BRI dream. The outcome of this long-standing friendship, we can see a great achievement in terms of China-Pakistan Economic Corridor (CPEC). CPEC projects needed to enhance the peace and stability in Pakistan. Pakistani and Chinese media both are playing a positive role in an outlook to make successful of CPEC projects. Pakistani and Chinese newspapers praised the progress of CPEC projects. There is need for proper understanding of this opportunity and Pakistan is not the only country that can serve as bridge. The news reports showed questions concerning about Pakistan and India cooperation or vice versa, both countries have tensed relationship since their history.

In above news reports Times of India reported dialogues of Pakistani and Chinese officials same as Pak-China newspapers reported, but further interpretation of Indian reporters making a huge difference in actual reports. Indian news reports raised the different issues that were presenting wrong interpretation to create hurdles in Pak-china relations. News report about china holding talk with Baluch militants in these news Pakistani officials welcomed China to talk with Baluch militants and talked about Chinese interference in internal matters of Pakistan but Indian newspaper reported it with wrong interpretation. Secondly about the issue of GB Indian newspaper reported in a different way in which they called the whole State of Jammu and Kashmir including the GB area is a part of India. In fact, GB is under the sovereignty of Pakistan and has fully rights to develop it. Third one is Chinese language courses launched in Pakistan to overcome communication barriers and this news Indian newspaper create a difference and reported that Pakistan have announced Chinese language as an official language. Such kind of showing that Indian media caught the news about CPEC projects to create a misunderstanding in Pak-china relations that somehow CPEC project could not run successfully.

\section{Legal Validity}

Historically the Gilgit-Baltistan can be divided into four different eras first one is $7^{\text {th }}$ century Ancient Era i.e. BC, and second one is $8^{\text {th }}$ to $18^{\text {th }}$ century era i.e. the Middle Ages (in this time period the religion Islam arrived), and the third one is 1840 to $1947-48$ in this time post-Liberation phase i.e. which Dogra rule. The Dogra's in 1840 of Kashmir assaulted on Baltistan region, 1947 to date, later he broadened to Gilgit occupying the area with the state of Jammu and Kashmir (Khan, 2017). In 1842 the people of Baltistan and in 1852 the people of Gilgit take to the stress against the Dogra's rule, as a result in 1842 Dogra reestablished Baltistan and 1860, in Gilgit. In 1846, the British in Punjab replaced the Sikhs (Riddick, 2006). Therefore, the British recognized and generally 
accepted the Gilgit Agency in 1876 (Yasin, 1984). From 26 March 1935 the British get the Gilgit agency for 60 years lease from Dogra's (Schofield, 2010). During this period The people of GB region not recognized to be valid the rule of Dogra as part of the state of Jammu and Kashmir. The Diamer region during this period remained free and the status was similar to the Tribal Areas (FATA) of Federal Administered. The Muslims of the subcontinent and the people of GB took action and defeated the rule of Dogra in 1947 of $1^{\text {st }}$ November in Gilgit after that newly state came into exist under the Pakistan (Brown, 2014). The people of tribal areas of Darel, Nagar, Hunza, Yasin, and Tangir was also interesting to being a part of Pakistan. The war of freedom against Dogra's rule was continued and defeated in August 1948, in result Baltistan become a part of Pakistan today known as the districts Shigar, Skardu, Kharmang, Ghanche (Afridi, 1988). GB in state of Pakistan fined accession in five phases those are as follow:

1. 7 November 1947, state of Yasin

2. 16 November 1947 , Gilgit

3. 19 November 1947, the states of Nagar and Hunza

4. in 1951-52, Darel and Tangir

\subsection{Aug 1948, Baltistan}

On 7 December 1947 Quaid-i-Azam Muhammad Ali Jinnah approved the documents agreement of Nagar and Hunza states with his signs. State rights over territory comprise a bundle of claims that include,

1. Rights to exercise jurisdiction (either full or partial) over those within the territory, and so to control and coerce in substantial ways even non-citizens within it;

2. Rights to reasonably full control over land and resources within the territory that are not privately owned;

3. Rights to tax and regulate uses of that which is privately owned within the state's claimed territory;

4. Rights to control or prohibit movement across the borders of the territory;

5. Rights to limit or prohibit “dismemberment” of the state's territories' (Simmons, 2001b, p. 306)

Indian media reports about Gilgit-Baltistan and Kashmir region presenting as a disputed territory because CPEC project will pass through Jammu and Kashmir region. New Delhi showed his anger and said Gilgit-Baltistan is "entirely unacceptable" because Pakistan treating like a separate province. In fact, Gilgit-Baltistan and Azad Kashmir both are under the sovereignty of Pakistan. India media raised such kind of questions to destruct the installation of CPEC and trying to create hurdles. New Delhi reaction and anger at CPEC routs in Kashmir include Gilgit-Baltistan area all is a part of India since 1947. The territory of a state has included the land name, subsoil; water, enclosed therein, land under the water, sea coast to a certain limit, airspace over the land mass and, territorial sea (http://www.un.org/depts/los/convention_agreements/texts/unclos/part2.htm). In legal perspective, territory normally indicates a geographical area that has been obtained by a particular country but has not been recognized as a full participant in that country's affairs. Gilgit-Baltistan is a province of Pakistan and included in the territory of Pakistan. Pakistan has a complete control of its territory and has rights to develop the region. China and Pakistan cleared that the CPEC will not creating any threat to others. President Xi also convinced the Modi to settle their disputes by table talk (https://en.wikipedia.org/wiki/Azad_Kashmir). Indian concerns have been raised in relation to the routing of the China Pakistan road through Pakistan-administered Kashmir (http://icwa.in/pdfs/IB/2014/CPECIB12052015.pdf).

\section{Discussion}

The BRI projects emphasis to build harmony and a momentous approach to meet the whole world under an umbrella and assists to know the issues and make available a peaceful way out to produce a harmonious world (Asif \& Ling, 2018). China Pakistan Economic Corridor CPEC is an important part of Chinese $21^{\text {st }}$ Silk Road Initiative that would be do good to for Pakistan and China as well as the whole region. It is very important to observe the local and international media reporting about this mega projects. Chinese and Pakistani media reporting about CPEC positively to complete this mega project successfully. These billions of dollars' investment and the visit of the Chinese president raise the confidence of investors to invest in Pakistan. But some international media are reporting immature and uncompleted news related to the security and legality of CPEC. These reports are not based on the reality but there is a need to make a good image of CPEC and there is need to observe such kind of immature and uncompleted news reporting to clarify these reports. Gilgit-Baltistan is a province of Pakistan and included the territory of Pakistan. Pakistan has a complete control of its territory and has rights to develop the region. China and Pakistan cleared that the CPEC will not creating any threat to other countries. President Xi also convinced the Modi to settle their disputes by table talk. India creating hurdles that 
somehow this project could not run successfully. CPEC projects will play a vital role in the economy of Pakistan and there is need to understand the various aspects and sensitivity of this multibillion-dollar project and it will bring peace and prosperity in the region. We have also needed to open the doors for legal cooperation among BRI countries (Ali \& Geng, 2018).

\section{References}

(2015, August 31). Retrieved Feburary 8, 2017, from Dawn: http//www.dawn.com.pk

Afridi, B. G. (1988). Baltistan in History (p. 232). Peshawar: Emjay Books International.

Ali, M., \& Geng, L. L. (2018). Legal Cooperation in Perspective of Belt and Road Initiative and China Pakistan Economic Corridor.

Arif, K. (1984). Documents on China-Pakistan Relations. Lahore: Vanguard.

Asif, M., \& Ling, Y. B. (2018). Belt and Road Initiative: A Spirit of Chinese Cultural Thought. International Journal of Business and Management, 13(12). https://doi.org/10.5539/ijbm.v13n12p9

BBC. (2015, April 20). China's Xi Jinping agrees $\$ 46$ bn superhighway to Pakistan. Retrieved from http;//www.bbc.com/news/worl-asia-32377088

Brown, W. A. (2014). Gilgit Rebellion: The Major who Mutinied over Partition of India (p. 139). Barnsley, South Yorkshire: Pen and Sword.

Chaudhri, M. (1970). Pakistan and the great powers. Karachi: Council for Pakistan Studies.

Chen, X., Banerjee, P., Toor, G. I., \& Downie, N. (2014). China and South Asia: Contention and cooperation between giant neighbours.

China Says AIIB Won't be Used for \$46 Billion Pakistan Deal. Reuters, April 17, 2015, http://in.reuters.com/article/2015/04/17/China-Pakistan idINKBN0N80RQ20150417.

China-Pakistan Economic Corridor 'Unacceptable", Modi Tells China. Express Tribune (Islamabad), International New York Times, June 1, 2015. Retrieved from http://tribune.com.pk/story/895611/China-Pakistan-economic-corridor-unacceptable-modi-tells-china/

Dixit, A. (1987) Sino-Paki Relations and Their Implications for India. Strategic Analysis, 11(9), 1067-1080

Godement, F. (2014). China's Neighbourhood Policy. European Council on Foreign Relations, Asia Centre.

http://forpakistan.org/fpdata/costs-and-benefits-of-cpec

http://www.globaltimes.cn/content/1090098.shtml

http://www.globaltimes.cn/content/1090101.shtml

http://www.globaltimes.cn/content/1097712.shtml

http://www.globaltimes.cn/content/1099826.shtml

http://www.globaltimes.cn/content/1103466.shtml

http://www.un.org/depts/los/convention_agreements/texts/unclos/part2.htm

https://abbtakk.tv/en/senate-approves-motion-to-declare-chinese-as-official-language/

https://en.wikipedia.org/wiki/Azad_Kashmir

https://icwa.in/pdfs/IB/2014/CPECIB12052015.pdf

https://timesofindia.indiatimes.com/world/pakistan/to-protect-cpec-china-has-been-secretly-holding-talks-with-b aloch-militants-in-pakistan-report/articleshow/62994826.cms

https://timesofindia.indiatimes.com/india/india-lodges-protest-with-pakistan-deputy-hc-over-gilgit-baltistan-orde r/articleshow/64343557.cms

https://timesofindia.indiatimes.com/india/india-refuses-to-endorse-chinas-bri/articleshow/64530284.cms

https://timesofindia.indiatimes.com/india/india-sticks-to-its-own-path-says-no-to-chinas-belt-road-initiative/artic leshow/63903471.cms

https://timesofindia.indiatimes.com/world/china/china-mum-on-pakistans-gilgit-baltistan-order-says-cpec-will-n ot-affect-its-stand-on-kashmir/articleshow/64367643.cms

https://timesofindia.indiatimes.com/world/pakistan/chinese-prisoners-working-on-cpec-in-pakistan-mp/articlesh 
ow/63133575.cms

https://timesofindia.indiatimes.com/world/pakistan/pakistan-suspects-india-may-target-cpec-installations-report/ articleshow/62791175.cms

https:/timesofindia.indiatimes.com/world/pakistan/to-protect-cpec-china-has-been-secretly-holding-talks-with-b aloch-militants-in-pakistan-report/articleshow/62994826.cms

https://timesofindia.indiatimes.com/world/south-asia/pakistan-will-give-more-financial-powers-to-pok/articlesho $\mathrm{w} / 64250565 . \mathrm{cms}$

https://www.aninews.in/news/world/asia/mandarin-approved-as-official-language-of-pakistan201802192310240 $006 /$

https://www.bbc.co.uk/news/world-asia-43158523

https://www.dawn.com/news/1387023

https://www.dawn.com/news/1387429

https://www.dawn.com/news/1390520

https://www.dawn.com/news/1392023

https://www.dawn.com/news/1397018

https://www.dawn.com/news/1402317

https:/www.financialexpress.com/world-news/cpec-effect-pakistan-tags-chinas-mandarin-as-official-language-m onth-after-replacing-dollar-with-yuan-for-bilateral-trade/1072356/

https:/www.indiatoday.in/world/story/ni-hao-pakistan-senate-motion-chinese-language-1173070-2018-02-19

Ijaz, A. (2016, May). Importance of CPEC. Retrieved Feburary 2017, from Pakistan Observer: http://www.thepakistanobserver.com/importance-of-cpec

Khan, E. M. (2017). The Role of Geography in Human Security: A Case Study of Gilgit-Baltistan (Doctoral dissertation, National Defence University (NDU) Islamabad).

Khan, T. (n. d.). Importance of Pak-China Economic Corridor. Retrieved Feburary 8, 2017, from Global Affairs: http:/www.globalaffairs.com.pk/importance-of-Pak-China-economic-corridor

Lu, A. (2015, April 20). China Pakistan Lift Ties to All-Weather Strategic Partnership of Cooperation. Retrieved from Xinhua News Agency: http://news.xinhua.net/english/2015-04/20/c-134167316.htm

Mahar, A. (2015, April 24). Why Chian's “One Belt, One Road” Initiative matter for Asia. Azernews.www.azernews.az/analysis/80980.html

One Belt One Road Provides New Drive for Regional Sustainable Development. (2016). Retrieved from People's Daily: http://en.people.cn/n3/2016/0408/c90000-9041876.html.

Paracha, S. (2016, January). Retrieved Feburary 9, 2017, from http:/www.google.com/article-by-shiraz-paracha-on-cpec

Rafi, A. E. (2016, July 11). Completion of CPEC: Impact on Pakistan's Strategic Position and Economy. Retrieved Feburary 9, 2017, from IPRI Review: http://www.iprireview.com/completion-of-cpec-impact-on-pakistan's-strategic-position-and-economy

Ranjan, A. (2015). The China-Pakistan Economic Corridor: India's Options. Institute of Chinese Studies Delhi, ICS Occasional Paper \# 10, 1.

Riddick, J. F. (2006). The History of British India: A Chronology (p. 48). London: Praeger.

Rizvi, D. H. (2015). The China Pakistan Economic Corridor: Regional Cooperation and Socio-Economic Development.

Retrieved from

ISSI: http;//issi.org.pk/wp-content/uploads/2015/12/Hasan-Askar-Rizvi-3435-SS-41-20142015.pdf

Schofield, V. (2010). Kashmir in Conflict: India, Pakistan and the Unending War (p. 25). New York: I.B. Tauris.

Simmons, A. J. (1992). The Lockean Theory of Rights. Cambridge: Cambridge University Press.

Syed, A. (1974). China \& Pakistan. Amherst, Mass: University of Massachusetts Press.

Tiezzi, S. (2016, Feburary 5). Pakistan will provide Special Force to defend Chinese Investments. Retrieved from The

Diplomat: 
http://thediplomat.com/2016/02/pakistan-will-provide-special-force-to-defend-chinese-investments/

Wang, J. (2015). China's 'New Silk road': A case study in Eu- China relations. In A. Amighini, \& A. Berkofsky (Eds.), Xi's Policy Gambles: The Bumpy Road Ahead (pp. 92-109). Beijing: ISPI.

Xinhuanet. (2013). Chinese premier hopes for more fruits in friendship with Pakistan. Xinhuanet.

Xu, S. (2015). Vision and Actions on Jointly Building Silk Road Economic Belt and 21st-Century Maritime Silk Road. National Development and Reform Commission, Ministry of Foreign Affairs, and Ministry of Commerce of the People's Republic of China, with State Council authorization, (2015). [Online] Retrieved from http://en.ndrc.gov.cn/newsrelease/201503/t20150330_669367.html [Accessed 22 Nov. 2015]

Yasin, M. (1984). British Paramountcy in Kashmir, 1876-1894 (p. 94). New Delhi, Atlantic Publishers.

\section{Copyrights}

Copyright for this article is retained by the author(s), with first publication rights granted to the journal.

This is an open-access article distributed under the terms and conditions of the Creative Commons Attribution license (http://creativecommons.org/licenses/by/4.0/). 